\title{
Synthesis of (6S)-6-hydroxy-4-epi-shikimic acid
}

\author{
Axel G. Griesbeck*, Claus Miara, and Jörg Neudörfl \\ Institut of Organic Chemistry, Greinstr. 4, D-50939 Köln/Cologne, Germany \\ E-mail: griesbeck@uni-koeln.de
}

Dedicated to Waldemar Adam on the occasion of his $70^{\text {th }}$ birthday

\begin{abstract}
The synthesis of the 6-hydroxylated epimer 7 of shikimic acid from natural shikimic acid $\mathbf{1}$ is conducted by a sequence of protecting steps, dehydration to the 1,3-cyclohexadiene $\mathbf{4}$ and photosensitized singlet oxygen cycloaddition reaction. The target molecule is then obtained from the endoperoxide 9 by reduction and deprotection. A new hydroxyl group is thereby inserted into position 6 of shikimic acid whereas the configuration at position 4 is formally inverted.
\end{abstract}

Keywords: Shikimic acid, singlet oxygen, Diels-Alder reaction, natural product

\section{Introduction}

Plants, microorganisms and fungi conduct the biosynthesis of aromatic amino acids from glucose by the shikimic pathway with shikimic acid $\mathbf{1}$ as key intermediate. ${ }^{1}$ Since this pathway does not occur in mammals, much effort has been made to synthesize potential enzyme inhibitors in order to develop antimicrobial reagents. ${ }^{2}$ Glyphosate $\mathbf{2}$ is an example for a highly active herbicide that operates by interfering with the shikimic pathway, where it inhibits 5-enolpyruvyl shikimate 3phosphate (EPSP) synthase, the sixth enzyme of the pathway. ${ }^{3}$ It is also able to inhibit the in vitro growth of Toxoplasma gondii, Plasmodium falciparum (malaria) and Cryptosporidium parvum. ${ }^{4}$ This proved that the shikimic pathway also takes place in apicomplexan parasites (malaria). Derivatives of shikimic acid are also of interest as enzyme inhibitors, e.g. antibacterial properties have been reported for $(6 S)$-6-fluoro-shikimic acid 3 (Figure 1). ${ }^{5}$ Although its effect is disputed, the drug oseltamivir (tamiflu ${ }^{\circledR}$ ) $4^{6}$ - a shikimic acid derivative - lately has become wellknown as a drug repressing the symptoms of the bird flu (avian influenza). ${ }^{7}$ Furthermore, the 4epi-shikimic acid skeleton ${ }^{8}$ is present in numerous natural products with interesting biological properties - one example is the (6S)-6-chloro derivative (5, pericosine A), an antitumour agent from Periconia byssoid. ${ }^{9}$ Synthetic efforts to new and efficient structural modifications of the shikimate skeleton are thus of high relevance. 
<smiles>O=C(O)C1=C[C@@H](O)[C@H](O)[C@H](O)C1</smiles>

1<smiles>O=C(O)CNCP(=O)(O)O</smiles>

2<smiles>O=C(O)C1=C[C@@H](O)[C@H](O)C(O)[C@H]1F</smiles>

3<smiles>CCOC(=O)C1=C[C@@H](N)C(NC(C)=O)[C@H](OC(CC)CC)C1</smiles>

Figure 1. Shikimic acid and pharmaceutically relevant derivatives.

In the context of our recent work on the photooxygenation of electron-deficient substrates, ${ }^{10}$ it appeared that shikimic acid (1) might behave similarly as tiglic acid with respect to its reactivity with electronically excited singlet oxygen $\left({ }^{1} \Delta_{\mathrm{g}^{-}}{ }^{1} \mathrm{O}_{2}\right)$. Tiglic acid (A) reacts by an ene reaction with ${ }^{1} \mathrm{O}_{2}$ with high regioselectivity and nearly quantitative yields. ${ }^{11} \mathrm{~A}$ similar reaction with 1 would introduce, after reduction, a hydroxy group exclusively at C-6 with formal epimerization at C-4 (Scheme 1). Additionally, shikimic acid exhibits the substructure of a chiral allylic alcohol like $\mathbf{C}$, substrates that are known to react with singlet oxygen highly regio- and diastereoselectively, albeit with 3-4 times lower rate constants than the corresponding nonhydroxylated alkenes. ${ }^{12}$ Thus, a cooperative regio- and stereocontrolling effect due to the two alkene motifs was expected in the dye-sensitized photooxygenation of $\mathbf{1}$ resulting in 6, a C6hydroxylated epimer of shikimic acid.

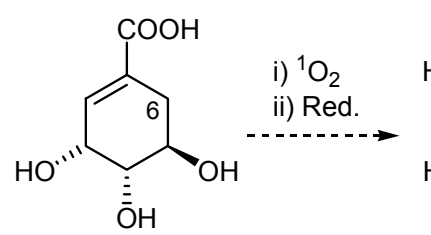

1<smiles>O=C(O)C1=C[C@@H](O)[C@@H](O)[C@H](O)[C@H]1O</smiles>

6<smiles>C=CC(=O)C(C)C(C)OO</smiles>

A

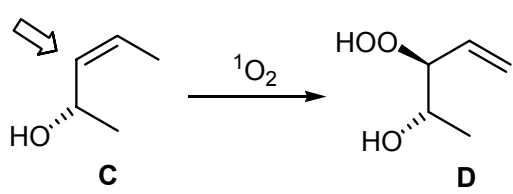

Scheme 1. Photooxygenation of model substrates with shikimic acid substructures. 


\section{Results and Discussion}

In a first row of experiments, we investigated the photooxygenation of the free acid $\mathbf{1}$. Due to the low solubility in most solvents, the photolyses were conducted in water or methanol with Rose Bengal (RB) as singlet oxygen sensitizer. Under these conditions no oxygen uptake was registered even after irradiation for days. Probably this reluctance originates from a combination of reduced singlet oxygen lifetime (some $\mu$ s in protic solvents) and the low reactivity of $\mathbf{1}$. In order to make the substrate more soluble, 1 was converted into its methyl ester and subsequently protected as acetal with 2,2-dimethoxypropane and catalytic amounts of camphorsulphonic acid (CSA) to give the acetonide $7 .{ }^{13}$ This substrate was sufficiently soluble also in $\mathrm{CCl}_{4}$, a solvent with a singlet oxygen lifetime of $59 \mathrm{~ms} .{ }^{14}$ Surprisingly, also under these conditions even after several days of irradiation in $\mathrm{CCl}_{4}$ no reaction with singlet oxygen occurred (Scheme 2).

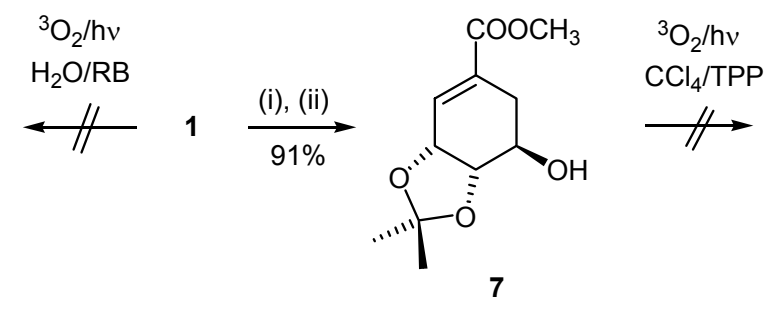

Scheme 2. Photooxygenation of shikimic acid and a protected derivative ( $\mathrm{RB}=$ Rose Bengal, $\mathrm{TPP}=$ meso-tetraphenylporphyrin): (i) $\mathrm{MeOH}$, CSA, (ii) dimethoxypropane, CSA.

After 3 days of irradiation of 3 under solid state conditions using a polystyrene matrix as the reaction media, ${ }^{15}$ a minor amount $(20 \%)$ of the substrate had reacted with introduction of a hydroperoxy functionality at C-3. Upon standing, this compound converted rapidly to the 3dehydro derivative and thus could not be used for our synthetic strategy. This result is probably due to radical conditions (type I photooxygenation) and not to a singlet oxygen process (type II photooxygenation). Thus, even under optimal conditions, the singlet oxygen ene reaction with 1 or 7, respectively, was not observed. A rationale is the combination of three effects: electronic deactivation by the carboxylate group, less favourable orientation of the allylic hydrogens in cyclohexene derivatives (as compared to the more reactive cyclopentenes) ${ }^{16}$ and a statistical factor (only one side of the double bond presents an pseudo-orthogonal allylic $\mathrm{CH}$ bond, see the simulation in Figure 2). 


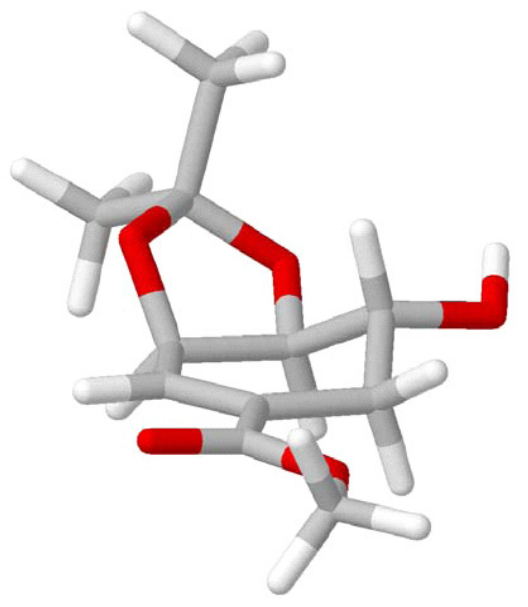

Figure 2. Simulated structure of substrate 7, MM+ force field calculation.

An alternative photooxygenation route to the target molecule 6 is the [4+2]-cycloaddition of ${ }^{1} \mathrm{O}_{2}$ to the corresponding 1,3-diene 8. This substrate is available from 7 by conversion into its triflate and base-induced elimination in $79 \%$ yield (Scheme 3 ). ${ }^{13}$ Photosensitized oxygenation of 8 under solution-phase conditions furnished the endoperoxide 9 in near quantitative yields. Under standard conditions the photooxygenation was complete after 7 hours, resulting in a colorless crystalline product after removal of the solvent. The NMR-data of the crude product showed full conversion of the diene and exclusive formation of one diastereoisomer. From the ${ }^{1} \mathrm{H}-\mathrm{NOE}$-experiments, the exo-configuration was postulated and this assumption was confirmed by a crystal structure analysis of 9 (Figure 3 ). ${ }^{17}$

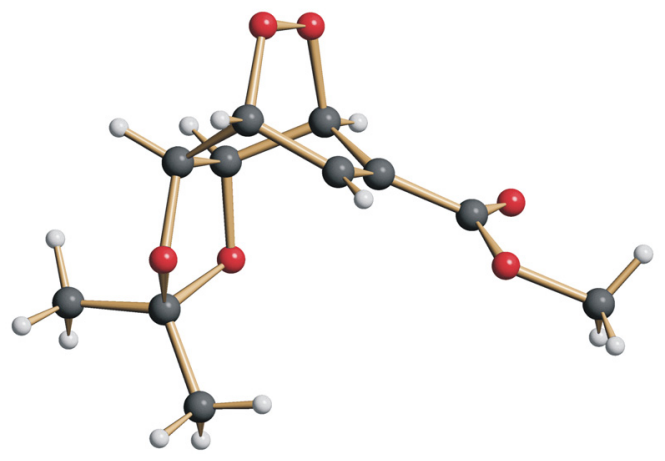

Figure 3. Structure of the endoperoxide 9 in the crystal. 


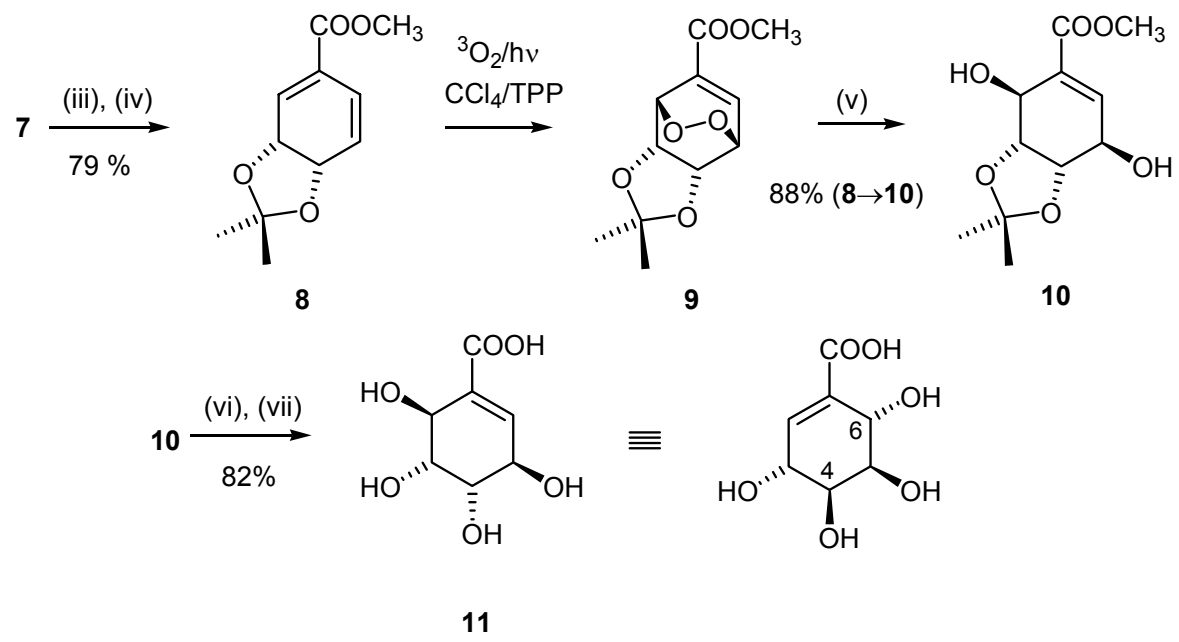

Scheme 3. Photooxygenation of the diene 8 and modifications to give the epimer 11: (iii) $\mathrm{Tf}_{2} \mathrm{O}$, pyridine, (iv) $\mathrm{CsCO}_{3}$, DMF, (v) KI, $\mathrm{H}_{2} \mathrm{O}-\mathrm{HOAc}$, (vi) $\mathrm{LiOH}, \mathrm{H}_{2} \mathrm{O}$, (v) $\mathrm{HCl}, \mathrm{MeOH}$.

Several variations were tested in order to upscale the photooxygenation of $\mathbf{8}$, driven by the fact that the reaction rate is still comparably slow and both substrate and product were unstable at ambient temperature and in the presence of acid (which is generated in chlorinated solvent after prolonged photooxygenation), respectively. The optimal solution is solid-phase photooxygenation in a polystyrene matrix doped with tetraphenylporphyrin at $5^{\circ} \mathrm{C}$ under a moisture-free oxygen atmosphere. The endoperoxide 9 was subsequently reduced with potassium iodide in presence of acetic acid ${ }^{18}$ to give the diol $\mathbf{1 0}$ in a yield of $94 \%$. Release of the protecting groups was eventually performed by basic saponification of the methyl ester with aqueous $\mathrm{LiOH}$ and removal of the acetonide by treatment with aqueous hydrochloric acid to yield (6S)-6hydroxy-4-epi-shikimic acid 11 in $82 \%$ yield.

In conclusion we accomplished a synthesis for the hitherto unknown (6S)-6-hydroxy-4-epishikimic acid 11 in a total yield of $52 \%$ by 8 steps from natural shikimic acid. The key photooxygenation step proceeded with high diastereoselectivity, the use of toxic transition metals or chlorinated solvents were avoided. Compound $\mathbf{1 1}$ is an interesting target for to examination of biological activity and further examinations are under way.

\section{Experimental Section}

General Procedures. Meso-tetraphenylporphyrin (TPP) was purchased from Porphyrin Systems; polystyrene beads (1\% divinylbenzene copolymer, 100-200 mesh) were purchased from Acros Organics. The solvents for solution photooxygenation were puriss. and used as purchased. NMR spectra were recorded on Bruker AC 250 and DPX 300 spectrometers, chemical shifts are given in $\delta$ (ppm) versus 0.0 (TMS for $\left.{ }^{1} \mathrm{H}\right)$ and $77.0\left(\mathrm{CDCl}_{3}\right.$ for $\left.{ }^{13} \mathrm{C}\right)$, multiplicities were determined by DEPT; IR spectra were obtained from a Perkin-Elmer 1600 
series FTIR spectrometer; melting points were determined with a Büchi melting point apparatus (type Nr. 535) and are uncorrected; CHN-combustion analyses were measured using an Elementar Vario EL instrument. Shikimic acid was obtained by extraction from Chinese star anise following ref. 19. Substrate 7 was synthesized from shikimic acid by a literature procedure. ${ }^{13}$ The MM+ force field calculation was performed with the HyperChem package version 7.0.

Methyl 7,8-isopropylidenedioxy-2,3-dioxabicyclo[2.2.2]oct-5-ene-5-carboxylate (8). Polystyrene beads (1\% copolymerized with divinylbenzene, 100-200 mesh) were swollen at room temperature with $\mathrm{CH}_{2} \mathrm{Cl}_{2}(20 \mathrm{ml} / 2 \mathrm{~g})$ in a flask and the solvent evaporated under reduced pressure. The substrate $7(1.26 \mathrm{~g}, 6.0 \mathrm{mmol})$ and $2 \mathrm{mg}$ of tetraphenylporphyrine were dissolved in $50 \mathrm{ml}$ of diethylether and mixed with the beads on a petri dish $(\varnothing=19 \mathrm{~cm})$. After evaporation of the excess solvent for $40 \mathrm{~min}$, the petri dish was sealed with a polyethylene film under an atmosphere of dried oxygen. The petri dish was placed on a stainless steel plate cooled to $5^{\circ} \mathrm{C}$ and irradiated by a $150 \mathrm{~W}$ tungsten-halogen lamp (20 cm distance lamp-plate). After $30 \mathrm{~h}$, the beads were treated with $30 \mathrm{ml}$ of ethyl acetate and the slurry was filtered by a glass frit. The beads were thoroughly washed with ethyl acetate and could be used for further reactions. The solvent was evaporated under reduced pressure and the crude colorless endoperoxide 9 (1.36 g, $94 \%)$ was directly used for reduction.

${ }^{1} \mathrm{H}-\mathrm{NMR}(300 \mathrm{MHz}) \delta\left(\mathrm{CDCl}_{3}\right)=1.19(\mathrm{~s}, 3 \mathrm{H}), 1.24\left(\mathrm{~s}, 3 \mathrm{H}, \mathrm{CH}_{3}\right), 3.77\left(\mathrm{~s}, 3 \mathrm{H}, \mathrm{CH}_{3}\right), 4.54(\mathrm{~m}$, $2 \mathrm{H}), 4.98(\mathrm{~m}, 1 \mathrm{H}), 5.38(\mathrm{dt}, 1 \mathrm{H}, J=4.6,1.8 \mathrm{~Hz}), 7.30(\mathrm{ddd}, 1 \mathrm{H}, J=6.3,1.8,0.6 \mathrm{~Hz},=\mathrm{CH}) .-{ }^{13} \mathrm{C}-$ NMR $(75 \mathrm{MHz}) \delta\left(\mathrm{CDCl}_{3}\right)=25.1\left(\mathrm{CH}_{3}\right), 25.6\left(\mathrm{CH}_{3}\right), 52.3\left(\mathrm{OCH}_{3}\right), 71.05,71.15,71.31,71.32$, $111.6\left(\mathrm{CMe}_{2}\right), 133.8\left(\mathrm{C}_{\mathrm{q}}\right), 138.0(\mathrm{CH}), 163.0(\mathrm{C}=\mathrm{O})$.- IR $v\left[\mathrm{~cm}^{-1}\right]$ 2956, 2930, 2871, 2795, 2455, 1717, 1592, 1457, 1378, 1260, 1028.- MS: $m / z$ HRMS (ESI) Found: $\left[\mathrm{M}+\mathrm{Na}^{+}\right]$265.069, $\mathrm{C}_{11} \mathrm{H}_{14} \mathrm{O}_{6}$ requires 265.0688.- m.p.: $101-102{ }^{\circ} \mathrm{C}$; Anal. Calcd for $\mathrm{C}_{11} \mathrm{H}_{14} \mathrm{O}_{6}: \mathrm{C}, 54.54 ; \mathrm{H}, 5.83$. Found: C, 54.52; H, 5.98 .

(3R, 4S, 5R, 6S) Methyl 4,5-Isopropylidenedioxy-3,6-dihydroxycyclohex-1-enecarboxylate (10). To a solution of $85 \mathrm{mg}(0.35 \mathrm{mmol})$ of the endoperoxide 9 in $10 \mathrm{ml}$ of diethylether was added a solution of $120 \mathrm{mg}$ of potassium iodine $(0.72 \mathrm{mmol})$ in $1 \mathrm{ml}$ of water and $0.1 \mathrm{ml}$ of acetic acid. The mixture was stirred at room temperature for $4 \mathrm{~h}$ and another $50 \mathrm{mg}$ of potassium iodine were added. After additional $2 \mathrm{~h}, 2 \mathrm{ml}$ of a concentrated solution of sodium thiosulfate was added followed by solid sodium thiosulfate until a colorless solution was obtained. After phase separation, the aqueous phase was extracted $3 \mathrm{x}$ by $\mathrm{Et}_{2} \mathrm{O}$, the organic phase combined and dried $\left(\mathrm{Na}_{2} \mathrm{SO}_{4}\right)$ and the solvent evaporated under reduced pressure resulting in $81 \mathrm{mg}(94 \%)$ of a clear viscous oil.

${ }^{1} \mathrm{H}-\mathrm{NMR}(300 \mathrm{MHz}) \delta\left(\mathrm{CDCl}_{3}\right)=1.28(\mathrm{~s} \mathrm{3H}), 1.29(\mathrm{~s}, 3 \mathrm{H}), 3.78(\mathrm{~s}, 3 \mathrm{H}), 4.33(\mathrm{dd}, 1 \mathrm{H}, J=5.0$, $3.0 \mathrm{~Hz}, \mathrm{CHOH}), 4.47$ (dd, 1H, J=7.0, 3.2 Hz, $\mathrm{CHOH}), 4.55$ (dd, 1H, J=7.0, $2.8 \mathrm{~Hz}, \mathrm{CHOH})$, $4.69(\mathrm{~d}, 1 \mathrm{H}, J=2.6 \mathrm{~Hz}, \mathrm{CHOH}), 7.20(\mathrm{~d}, 1 \mathrm{H}, J=5.3 \mathrm{~Hz},=\mathrm{CH}) \cdot-{ }^{13} \mathrm{C}-\mathrm{NMR}(75 \mathrm{MHz}) \delta\left(\mathrm{CDCl}_{3}\right)$ $=24.2\left(\mathrm{CH}_{3}\right), 26.2\left(\mathrm{CH}_{3}\right), 52.3\left(\mathrm{OCH}_{3}\right), 65.1(\mathrm{CH}), 66.2(\mathrm{CH}), 77.2(\mathrm{CH}), 77.7(\mathrm{CH}), 108.7$ $\left(\mathrm{CMe}_{2}\right), 134.5\left(\mathrm{C}_{\mathrm{q}}\right), 142.1(=\mathrm{CH}), 166.4(\mathrm{C}=\mathrm{O})$.- 
$m / z$ HRMS (ESI) Found: $\left[\mathrm{M}+\mathrm{Na}^{+}\right]$267.084, $\mathrm{C}_{11} \mathrm{H}_{16} \mathrm{O}_{6}$ requires 267.06845.- IR: $v\left[\mathrm{~cm}^{-1}\right]$ 2982, $2935,1720,1435,1381,1254,1208,1164,1055,1032 .-[\alpha]_{D}=-19.9\left(c 0.61 ; \mathrm{CHCl}_{3}\right)$.

\section{$(3 R, 4 S, 5 R, 6 S) 3,4,5,6$-Tetrahydroxycyclohex-1-ene carboxylic acid (11)}

\section{(a) Saponification:}

A solution of $81 \mathrm{mg}(0.36 \mathrm{mmol})$ of $\mathbf{1 0}$ in a mixture $2 \mathrm{ml}$ of water and $0.5 \mathrm{ml}$ of THF was treated with $67 \mathrm{mg}(2.79 \mathrm{mmol})$ of $\mathrm{LiOH}$. After stirring for $1 \mathrm{~h}$ at room temperature, the mixture was diluted with $10 \mathrm{ml}$ of water and $20 \mathrm{ml}$ of ethyl acetate and acidified with Dowex 50 X 8 ion exchange resin. After stirring for $15 \mathrm{~min}$, the solution was filtered and the clear solution extracted with $2 \times 30 \mathrm{ml}$ of ethyl acetate, dried $\left(\mathrm{Na}_{2} \mathrm{SO}_{4}\right)$ and evaporated to give $75 \mathrm{mg} 11(90 \%)$ of a colorless powder.

${ }^{1} \mathrm{H}-\mathrm{NMR}(300 \mathrm{MHz}) \delta\left(\mathrm{CDCl}_{3}\right)=1.30(\mathrm{~s}, 6 \mathrm{H}), 4.37(\mathrm{dd}, 1 \mathrm{H}, J=4.8,2.8 \mathrm{~Hz}), 4.51(\mathrm{dd}, 1 \mathrm{H}, J=$ 6.8, $4.9 \mathrm{~Hz}), 4.55(\mathrm{dd}, 1 \mathrm{H}, J=6.8,2.7 \mathrm{~Hz}), 4.71(\mathrm{~d}, 1 \mathrm{H}, J=2.5 \mathrm{~Hz}), 7.31(\mathrm{~d}, 1 \mathrm{H}, J=5.1 \mathrm{~Hz}$, $=\mathrm{CH}) .{ }^{13} \mathrm{C}-\mathrm{NMR}(75 \mathrm{MHz}) \delta\left(\mathrm{CDCl}_{3}\right)=24.2\left(\mathrm{CH}_{3}\right), 26.2\left(\mathrm{CH}_{3}\right), 64.9(\mathrm{CH}), 66.2(\mathrm{CH}), 77.1$ $(\mathrm{CH}), 77.6(\mathrm{CH}), 108.9\left(\mathrm{C}_{\mathrm{q}}\right), 133.9\left(\mathrm{C}_{\mathrm{q}}\right), 143.9(=\mathrm{CH})$; $169.6(\mathrm{C}=\mathrm{O}) .-\mathrm{IR}: v_{\max }\left[\mathrm{cm}^{-1}\right]=2989$, 2918, 1697, 1432, 1376, 1262, 1211, 1162, 1058, 1024.-

(b) Acetal cleavage:

To a solution of $60 \mathrm{mg}(0.26 \mathrm{mmol})$ of the acetal-protected compound in $2.5 \mathrm{ml}$ of water and 2.5 $\mathrm{ml}$ of methanol was added 2 drops of concentrated $\mathrm{HCl}$ under vigorous stirring at room temperature. The reaction mixture was stirred overnight and the solvent evaporated under reduced pressure. The residue was repeatedly dissolved in ethanol and the solvent evaporated to give $45 \mathrm{mg}(91 \%)$ of a colorless powder, m.p.: $140-141^{\circ} \mathrm{C}$.

${ }^{1} \mathrm{H}-\mathrm{NMR}(300 \mathrm{MHz}) \delta\left(\mathrm{d}_{4}-\mathrm{MeOH}\right)=3.51(\mathrm{dd}, 1 \mathrm{H}, J=8.1,2.1 \mathrm{~Hz}, \mathrm{CH}), 3.86(\mathrm{dd}, 1 \mathrm{H}, J=3.1$, $2.4 \mathrm{~Hz}, \mathrm{CH}), 4.23(\mathrm{dd}, 1 \mathrm{H}, J=8.0,1.9 \mathrm{~Hz}, \mathrm{CH}), 4.39$ (d, 1H, $J=3.1 \mathrm{~Hz}, \mathrm{CH}), 6.75(\mathrm{~d}, 1 \mathrm{H}, J=$ $2.4 \mathrm{~Hz},=\mathrm{CH}) \cdot-{ }^{13} \mathrm{C}-\mathrm{NMR}(75 \mathrm{MHz}) \delta\left(\mathrm{CDCl}_{3}\right)=69.2(\mathrm{CH}), 69.9(\mathrm{CH}), 72.1(\mathrm{CH}), 75.3(\mathrm{CH})$, $131.6\left(\mathrm{C}_{\mathrm{q}}\right), 143.5(=\mathrm{CH}), 169.5(\mathrm{C}=\mathrm{O}) .-m / z$ HRMS (ESI) $\left[\mathrm{M}-\mathrm{H}^{+}\right] 189.260-\mathrm{IR}: v_{\max }\left[\mathrm{cm}^{-1}\right]=$ 3308, 2936, 1692, 1636, 1415, 1259, 1092, 1072, 1028, 797.

\section{Acknowledgements}

This research was supported by the Deutsche Forschungsgemeinschaft and by a University startup funding (2004-2005).

\section{References}

1. Haslam, E., Shikimic Acid: Metabolism and Metabolites John Wiley: Chichester, 1993.

2. Kishore, G. M.; Shah, D. M. Ann. Rev. Biochem. 1988, 57, 627.

3. Sikorski, J. A.; Gruys, K. J. Acc. Chem. Res. 1997, 30, 2. 
4. Roberts, F.; Roberts, C. W.; Johnson, J. J.; Kyle, D. E.; Krell, T.; Coggins, J. R.; Coombs, G. H.; Milhous, W. K.; Tzipori, S.; Ferguson, D. J. P.; Chakrabarti, D.; McLeod, R. Nature 1998, 393, 801.

5. Davies, G. M.; Barrett-Bee, K. J.; Jude, D. A.; Lehan, M.; Nichols, W. W.; Pinder, P. E.; Thain, J. L.; Watkins, W. J.; Wilson, R. G. Antimicrob. Agents Chemother. 1994, 38, 403. (b) Ewart, C. D. C.; Jude, D. A.; Thain, J. L.; Nichols, W. W., Antimicrob. Agents Chemother. 1995, 39, 87-93. (c) Jude, D. A.; Ewart, C. D.; Thain, J. L.; Davies, G. M.; Nichols, W. W., Biochim. Biophys. Acta 1996, 1279, 125.

6. Recent syntheses: (a) Yeung, Y.-Y.; Hong, S.; Corey, E. J. J. Am. Chem. Soc. 2006, 128, 6310. (b) Fukuta, Y.; Mita, T.; Fukuda, N.; Kanai, M.; Shibasaki, M. J. Am. Chem. Soc. 2006, 128, 6312 .

7. Kim, C. U.; Lew, W.; Williams, M. A.; Liu, H.; Zhang, L.; Swaminathan, S.; Bischofberger, N.; Chen, M. S.; Mendel, D. B.; Tai, C. Y.; Laver, W. G.; Stevens, R. C. J. Am. Chem. Soc. 1997, 119, 681.

8. Recent synthesis: Sánchez-Abella, L.; Fernández, S. ; Armesto, N.; Ferrero, M.; Gotor, V. J. Org. Chem. 2006, 71, 5396.

9. Usami, Y.; Horibe, Y.; Takaoka, I.; Ichikawa, H.; Arimoto, M. Synlett 2006, 1598. Original report with incorrect configuration: Numata, A.; Iritani, M.; Yamada, T.; Minoura, K.; Matsumura, E.; Yamori, T.; Tsuruo, T. Tetrahedron Lett. 1997, 38, 8215.

10. Griesbeck, A. G.; Höinck, L.-O.; Lex, J. Lett. Org. Chem. 2006, 3, 247.

11. Adam, W.; Griesbeck, A., Angew. Chem. Int. Ed. Engl. 1985, 24, 1070.

12. Griesbeck, A. G.; Adam, W.; Bartoschek, A.; El-Idreesy, T. T. Photochem. Photobiol. Sci. 2003, 2, 877.

13. Song, C.; Jiang, S.; Singh, G. Tetrahedron Lett. 2001, 42, 9069.

14. Schweitzer, C.; Schmidt, R. Chem. Rev. 2003, 103, 1685.

15. Griesbeck, A. G.; Bartoschek, A.; El-Idreesy, T. T.; Höinck, O.; Maira, C. J. Mol. Cat. A: Chem. 2006, 251, 41.

16. Griesbeck, A. G.; El-Idreesy, T. T.; Adam, W.; Krebs, O., in CRC Handbook of Organic Photochemistry and Photobiology, (eds.: Horspool, W. M.; Lenci, F.), CRC Press: Boca Raton, 8/1-8/20 (2004).

17. X-ray structure of 9: empirical formula $\mathrm{C}_{11} \mathrm{H}_{14} \mathrm{O}_{6}$, formula weight: 242.22 , space group monoclinic: P21, unit cell dimensions: $\mathrm{a}=16.6869(6) \AA, \alpha=90^{\circ}, \mathrm{b}=5.93000(10) \AA, \beta=$ 105. 0562(10) $)^{\circ} \mathrm{c}=23.9425(9) \AA, \gamma=90^{\circ}$, final $\mathrm{R}$ indices $[\mathrm{I}>2 \operatorname{sigma}(\mathrm{I})] \mathrm{R} 1=0.0654$, $\mathrm{wR} 2=0.1590 ; \mathrm{R}$ indices (all data) $\mathrm{R} 1=0.0952, \mathrm{wR} 2=0.1822$.

18. Rio, G.; Charifi, M., Bull. Soc. Chim. Fr. 1970, 3585-3593.

19. Adams, H.; Bailey, N. A.; Brettle, R.; Cross, R.; Frederickson, M.; Haslam, E.; MacBeath, F. S.; Davies G. M. Tetrahedron 1996, 52, 8565-8580; recently published alternative: Payne, R.; Edmonds, M., J. Chem. Ed. 2005, 82, 599-600. 